\title{
SIMPLE APPARATUS FOR USE IN APPLIED MATHEMATICS.
}

\author{
By J. Steph. van der Lingen.
}

(From the Applied Mathematics Laboratory, South African College.)

(Received April 9, 1915.)

\section{I.-Apparatus for Finding "G."}

Teachers of applied mathematics generally find some difficulty in satisfying the queries of students who desire to have some definite idea about the acceleration of a freely falling body.

The following is a brief description of a simple piece of apparatus which does not involve assumptions of dynamical quantities which the beginner cannot determine for himself (see Fig. 1).

The axis, A, of a rigid pendulum is firmly screwed on to a board on a wall.

Vertically above A a clamp, F, is screwed on a fixed board so that the rod, s, may be clamped at various heights above or below A.

The rod, s, carries an electro-magnet, $\mathrm{m}$, which is connected electrically to т $\mathrm{T}$ by means of flexible wire.

Below в, the movable bob of the pendulum, a light platform, $\mathrm{P}$, is clamped by screws on to the rod.

At $\mathrm{H}$, the centre of $\mathrm{P}$, an hole is cut so that a steel ball may fall freely through it.

When the rod of the pendulum is hooked by the catch, c, an electric current passes through $\mathrm{R}$, the variable resistance, and $\mathrm{m}$.

$\mathrm{R}$ is varied until the steel ball is just held up by м.

On releasing the pendulum at $\mathrm{c}$ the ball begins to fall.

The height $(\mathrm{h})$ of $\mathrm{m}$ above $\mathrm{H}$ is increased or decreased according as the ball falls to the left or right of $\mathrm{H}$ until the ball just falls through $\mathrm{H}$.

A piece of paper with a central line on it is now placed over $\mathrm{H}$, and the ball at m slightly inked at its lowest point.

The height of $\mathrm{n}$ is now set so that the ball falls on the central line.

The height " $h$ " is now measured, and also the diameter of the ball.

The time of vibration is now found by observing the time that the pendulum takes to make a hundred vibrations.

The beginner immediately sees that the ball fell through a height " $h$ " 
in the same time that the pendulum takes to make one-half of an oscillation, hence he is enabled to find " $\mathrm{g}$. ."

The time of vibration is then varied by moving $\mathrm{B}$ along the length of the pendulum and a second set of observations recorded.

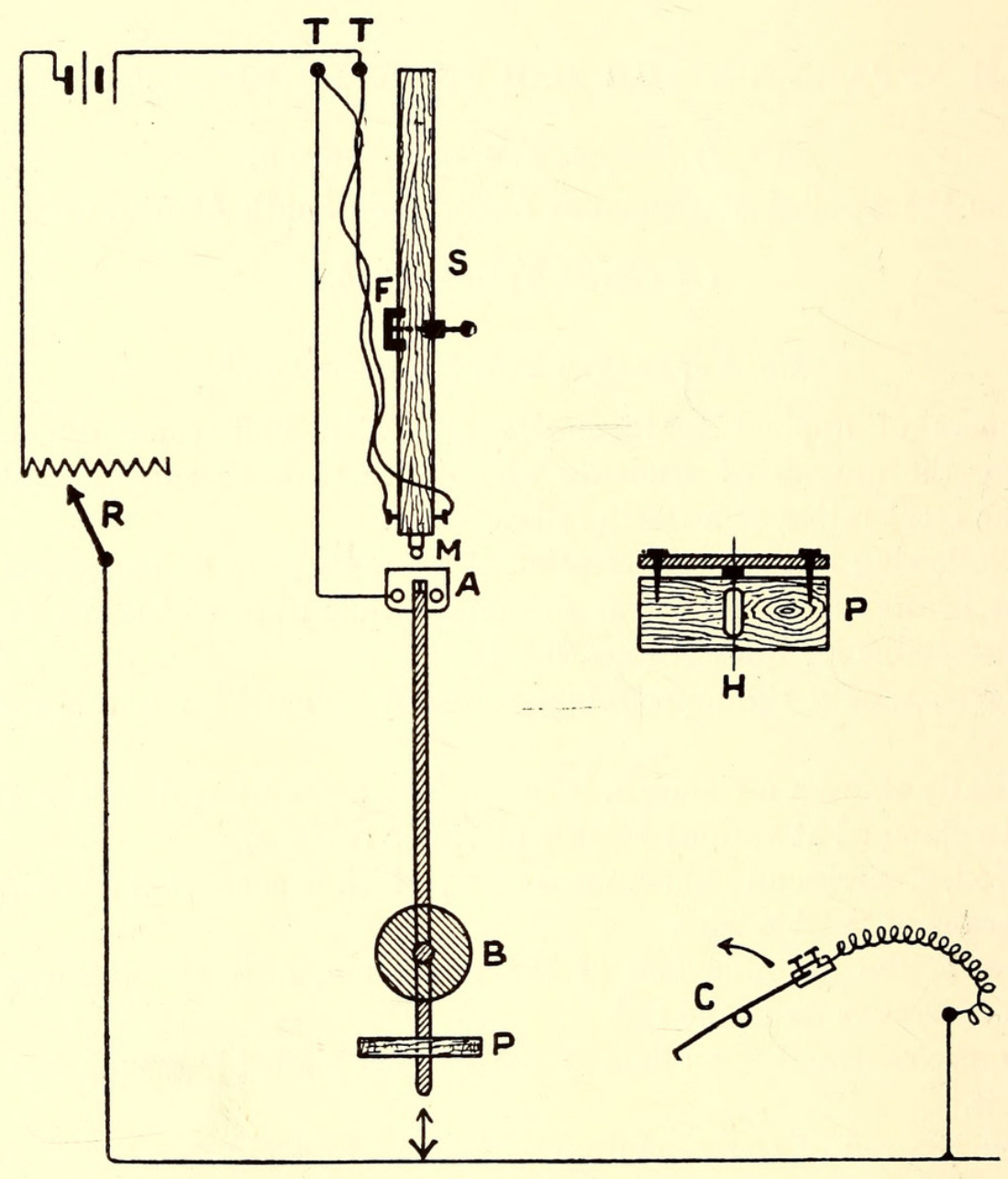

Fig. 1.

Record of Results obtained by Elementary Students.

$$
\begin{aligned}
& \text { Cand. I. } \mathrm{g}=984,981,1003 \text {. } \\
& \text { „ II. „, 977, } 991 \text {. } \\
& \text {, III. „, 994, 986, } 1030 . \\
& \text {, IV. „, 993, } 1035 . \\
& \text { „ V. „, 991, } 966 \text {. } \\
& \text { „ VI. „ } \quad 976,981,981 . \\
& \text { „ VII. „, 971, 987, } 980 . \\
& \text { „ VIII. „, 964, } 979 .
\end{aligned}
$$

The best results are naturally obtained when the time of vibration is 
short and when the ball is not magnetised. After each observation the ball is demagnetised.

This apparatus does not involve any dynamical knowledge of quantities which the beginner cannot determine for himself.

\section{II.-Standardizing a Given Vibrator.}

Another difficulty which presents itself to the beginner is that he must assume the time of vibration of some vibrator when he is asked to determine velocities and accelerations of trolleys, etc.

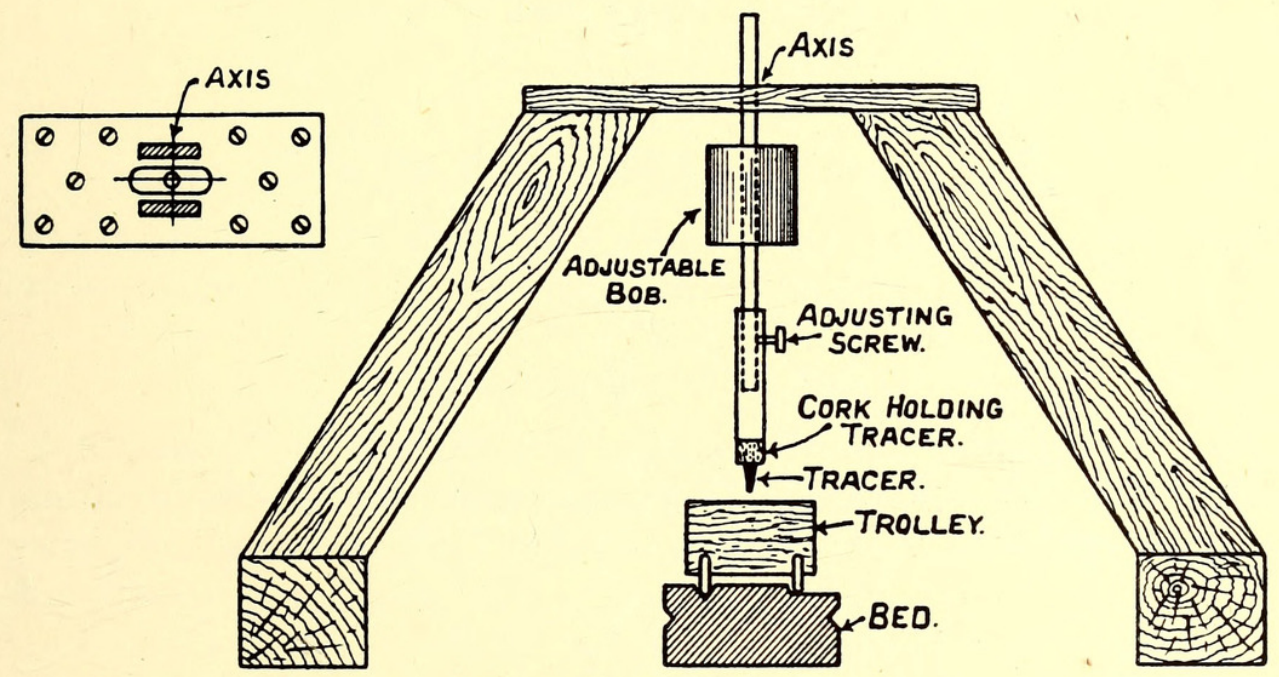

FIG. 2.

The piece of apparatus figured enables the student to determine the period of vibration of the vibrator (Fig. 2).

The pendulum vibrates perpendicularly to the direction of motion of the trolley, and thus crosses the trace of the vibrator after definite intervals of time.

The trolley is given a light tap so that it moves with practically uniform velocity under the pendulum and vibrator.

When the velocity is small a large number of vibrations will be recorded on the paper.

The brush of the pendulum and that of the vibrator are set as closely together as possible.

If the pendulum's zero is at A and the vibrator's at B, then in going from A to $\mathrm{c}$ it executes $n$ oscillations, and the vibrator executes $\mathrm{m}$ oscillations in an equal distance measured from в.

Hence $\frac{\mathrm{T} p}{\mathrm{~T} v}=\frac{\mathrm{M}}{n}$, where $\mathrm{T} p$ is the period of the heavy rigid pendulum. т $p$ 
is now determined by recording the time $20,40,60,80,100$, etc., vibrations.

Finally $\mathrm{\tau} v=\mathrm{T} p \frac{n}{\mathrm{M}}$ seconds.

This also enables students to determine the variation of $\mathrm{T}$ when the length of the vibrator is increased or decreased. ( $\mathrm{p} p$ for the pendulum used in the South African College Laboratory is 0.8 secs. Minimum тp for the above pendulum is 0.68 secs.)

Applied Mathematics Laboratory,

South African College, Cape Town. 


\section{$2 \mathrm{BHL}$ Biodiversity Heritage Library}

Lingen, J. Steph. van der. 1915. "SIMPLE APPARATUS FOR USE IN APPLIED MATHEMATICS." Transactions of the Royal Society of South Africa 5, 599-602. https://doi.org/10.1080/00359191509519731.

View This Item Online: https://www.biodiversitylibrary.org/item/181589

DOI: https://doi.org/10.1080/00359191509519731

Permalink: https://www.biodiversitylibrary.org/partpdf/175556

\section{Holding Institution}

Smithsonian Libraries

\section{Sponsored by}

Biodiversity Heritage Library

\section{Copyright \& Reuse}

Copyright Status: Not in copyright. The BHL knows of no copyright restrictions on this item.

This document was created from content at the Biodiversity Heritage Library, the world's largest open access digital library for biodiversity literature and archives. Visit BHL at https://www.biodiversitylibrary.org. 